\title{
Inclusive Education: Trends and Challenges in India
}

\author{
Dr. Yogeshver Prasad Sharma*
}

Assistant Professor, Department of Education, Shri Venkateshwara University, Rajabpur, Gajraula, Distt.- Amroha (U.P.) India

DOI: $10.36348 /$ sjnhc.2019.v02i11.003

| Received: 19.10.2019| Accepted: 27.10.2019| Published: 12.11.2019

*Corresponding author: Dr. Yogeshver Prasad Sharma

\section{Abstract}

Inclusive education is brought about by having all children of society to become students of the same schools. So, inclusive education means, "The act of ensuring that all children despite their differences, receive the opportunity of being part of the same classroom as other children of their age, and in the procedure get the opportunity of being showing to the curriculum to their optimal potential". Every child is special for his/her parent. And, every child has a special need for love, acceptance and a feeling of belongingness. However it gives them a whole perspective with respect to dealing with diversity or challenge negative attitudes. The trends and challenges in India are elucidated in the present paper.

Keywords: Inclusive Education, Teachers, Policy Makers, Trends, Challenges, Etc.

Copyright @ 2019: This is an open-access article distributed under the terms of the Creative Commons Attribution license which permits unrestricted use, distribution, and reproduction in any medium for non-commercial use (NonCommercial, or CC-BY-NC) provided the original author and source are credited.

\section{INTRODUCTION}

Inclusive education denotes that every child irrespective of their strengths and weaknesses will be part of the mainstream education the feeling of belongingness among all community members teachers, students and other functionaries is developed through inclusive education. Inclusive education is for all, irrespective of any social community, caste, class, gender and disability of the child.

\section{Trends and developments in provisions in india}

Trends in provisions in India reflect that the leading strategy predisposition before the 1970s has been that of segregation. In $1880 \mathrm{~s}$ Christian missionaries started school for the disabled on ground of Charity. This was followed by the government initiatives to establish separate workshops, Model schools, central Braille prices and employment exchanges for the disabled population of the country. However, the changing approaches to disability from the charity model to the human rights model have resulted in diversity of policy and practice. In the 1970s the Integrated Education for the Disabled Children (IEDC) scheme was launched by the Union Government for providing educational opportunities to learners with Special Educational Needs (SEN) in regular schools. Nevertheless, the statistics show that though the integration of learners with Special Educational Needs (SEN) gathered some momentum, the coverage under this scheme remained inadequate. There was a clear requirement for fuller access of children with SEN to all educational opportunities.
Dissatisfaction with the slow progress towards integration along with the consideration of the costs involved led to a demand for a radical change. After the World Conference on Special Needs Education in Salamanca in 1990s, inclusion became the magic word in the educational field. The Salamanca report adopted by representatives of 92 Governments and 25 International Organizations has, in fact, set the policy agenda for inclusive education on a global basis. Inclusive education refers to all learners, young people with or without disabilities being able to learn together in ordinary pre-school provisions, schools and community educational settings with appropriate network of support services.

The 1995 Persons with Disability Act (PDA) states that disabled children should be educated in integrated settings where possible, although it seems that the lack of implementation may be due to there being no enforcement organization for this legislation.

UNICEF's Report on the Status of Disability in India 2000 states that there are around 30 million children in India suffering from some form of disability. The sixth all India educational survey [1] reports show that of India's 200 million school - aged children (6-14 years), 20 million require special needs education. While the national average for gross enrolment in school is over $90 \%$, less than $5 \%$ of children with disabilities are in school. Government and NGOs are starting measures to review and plan appropriate Strategies for special needs and inclusive education. 
These measures include evolving policy guidelines, analyzing practices, developing teachers training programmes, and creating resource person and special teachers by establishing linkages to complement each other.

In the Past few years, focus on children with disabilities has resulted in greater awareness and the sensitivity towards these children. The launch of the District Primary Educational Programme (DPEP) in 1994 provided further impetus to existing efforts. The Equal Opportunities and Right of Persons with Disabilities Act 1995 was comprehensive break throw legislation that provided for education and economic rehabilitation of people with disabilities. It states that free education for children with disabilities up to the age of 18 years must be provided in an appropriate environment. The government has just launched the Sarva Shiksha Abhiyan (SSA) this proposes to implement "Universalization of Elementary Education' (UEE) in a mission mode with a focus on providing quality elementary education to all children in the age group 6-14 years. Inclusive education is an integral component of SSA, and promise to make "Education for All" a reality. But these all great and ideal still continue as a myth.

\section{Challenges in inclusion}

There could be many berries for educating children with disabilities in regular classrooms. It is evident from the experience of children with disabilities and their families, in an inclusive school environment. These barriers could emanate from scarcity of resources, negative attitude of teachers, not disabled peers and their parents. The peers in school being the closest on par play an important role in the lives of the children with disabilities. There is general support for the hypothesis that children who are not accepted by peers are generally at risk for difficulties later in life [2].

Inclusive education must reaction to all pupils as individuals, recognizing individuality as something to be appreciated and respected. Inclusive education responding to special needs will thus have positive returns for all pupils all children and young people of the world, with their individual strengths and weaknesses, with their hopes and expectation. So the current attention/focus will be on the implementations and its follow up. This is the need of the hour.

\section{Policy and special education in india}

The Government of India has created many policies around special education since the country's independence in 1947. Although the Government of India has attempted to create policies that are inclusive for people with disabilities, their implementation efforts have not resulted in an inclusive system of education, nor have they reached their goal of "education for all" across the country. The Government of India needs to bridge the gap in their education system to build a strong system of inclusive education in India.

The national policy on education, 1986 [4] and the programme of action [4] stresses the need for integrating children with special needs with other groups. The objectives to be achieved as stated in the NPE, 1986 is "to integrate the physically and mentally handicapped with general community as equal partners, to prepare them for normal growth and to enable them to face life with courage and confidence".

The constitution of India does not explicitly include children with disabilities in the provisions made for education, but Article - 41 does mention people with disabilities and says in part "the State sale within the limits of its economic development make effective provisions for securing the right to work, to education and to public assistance in case of unemployment, old age, sickness, disablement and in other cases of undesired want". It does not mandate the free and compulsory education as a fundamental right and is merely a directive principle to guide State Policy but Article - 45 does rectify this by stating that free and compulsory education should be provided for ALL children until they complete the age of 14 years. The ALL is never specifically explained.

On the 21st of March 2005, the Honorable Minister of Human Resource Development in the Rajya Sabha presented a comprehensive statement on the subject of inclusive education of children with disabilities. Inclusion in relation to all groups seen as being vulnerable to exclusion, inclusion as developing the school for all, inclusion as 'Education for All', inclusion as a principle, approach to education and Society. These different interpretations of inclusive education indicate that there is conceptual confusion surrounding this.

\section{World perspective on inclusive education}

In the world's population $10 \%$ of lives with disability, and $80 \%$ of these people with disabilities live in developing countries, the services available for people with disabilities. Differ wildly between developed and developing countries. One of these services is education. The International Community, specifically since the UN Convention on People with Disabilities, is becoming increasingly aware of the different models of special education. The three basic models, segregated, integrated and inclusive special education, have been differentiated between by international and governmental agency, and overwhelming support is being shown by human rights activists, nonprofits, governmental organization, governments and international agencies, all in favour of inclusive special education as the most beneficial type of education for people of all ability levels. 
People who believe in inclusive education believe that the education system is the impediment to learning for a child, and that every child is capable of learning! It is important to note that within government documents and scholarly publication in India.

\section{Gaps in the education system in india}

We have seen progress in governmental policies that point toward efforts of inclusion in mainstream education in India. However, the current statistics and literature point to an entirely different situation on the ground. Well- intentioned policy makers are having issues with the implementation of their policies. A study was presented at a seminar called "Integrated Education for Children with Special Needs: a Matter of Social Justice and Human Rights" in Delhi in 1997. This study examined by students dropped out of mainstream schools in India before and enrolling in a particular special school. There were many reasons identified. Students repeatedly failed their courses and were asked to leave by teachers for administrators, and many of these students were teased for their "failure". Many students said that the teachers at their old school would erase lessons off of the board before students were finished copying them. Other students said they were never moved up beyond nursery level classes, and found it embarrassing to be in Lower classes with children younger than them. Students were often isolated in class, or said they had no friends at school. Many were hyperactive or had behaviour issues and were asked to leave. In the past, the role of NGOs has been running special schools that were responsible for the education of children with disabilities.

\section{CONCLUSION}

It is important to remember that Inclusive education is at a very early stage of conceptualization and implementation in India. Programmes launched in the recent past have been able to make only a limited impact in term of increasing the participation of children with disabilities in formal education. This situation needs to change in the near future, and a focused effort is required. Keeping in mind the large number of children whose needs must be addressed and the limited resources available, the best option is to promote inclusive education. However, the question is how to demystify the concept and make it admissible in a country as large and diverse as India, with its multiple tracks offering inequitable schooling opportunities to different groups? There is a need to develop a long-term strategy in which every step taken plus to the sound base for inclusive education. This can be facilitated by developing a better understanding of the current status of education of children with disabilities, and how inclusive practices can be promoted.

\section{REFERENCES}

1. Maheshwari, A. N., \& Raina, V. K. (1998). Inservice training of primary teachers through interactive video technology: An Indian experience. International Review of Education, 44(1), 87-101.

2. Ochoa, S. H., \& Olivarez Jr, A. (1995). A metaanalysis of peer rating sociometric studies of pupils with learning disabilities. The Journal of Special Education, 29(1), 1-19.

3. Ainscow, M. (2005), "From Special Education to Effective Schools for All, Keynote presentation at the Inclusive and Supportive Education Congress 2005”, University of Strathclyde, Glasgow.

4. UNESCO. (1994). "The Salamanca Statement and Framework on Special Needs Education". Paris: UNESCO.

5. Hegarty, S., \& Alur, M. (Eds.). (2002). Education \& Children with Special Needs: From Segregation to Inclusion. Sage.

6. Balagopalan, S., \& Subrahmanian, R. (2003). Dalit and Adivasi children in schools: some preliminary research themes and findings. IDS Bulletin, 34(1), 43-54.

7. GOI. (2003). Annual Report (2002-2003), "Department of Elementary Education and Literacy, Department of Secondary Education and Higher Education, Ministry of Human Resource Development", New Delhi: Government of India.

8. Thamarasseri, Ismail. (2012). "Trends and Developments in Social Science Education". New Delhi: Kanishka Publishers. 